\title{
Diagnosis of Customer Expectations and Perceptions in Restaurants in the State of Tlaxcala
}

\author{
Sandra Karina Saldaña Conde, Crisanto Tenopala Hernández, Elizabeth Montiel Huerta, \\ Gerardo Islas Téllez, and Alejandra Torres López
}

\section{ABSTRACT}

The restaurant industry is one of the main productive sectors in Mexico that generates an important economic benefit for the country, Mexican food in particular is recognized throughout the world for its great value and historical contribution. Derived from its importance, it is significant to consider offering quality customer service; However, if you want to improve the Mexican food restaurant sector, you must start by addressing all the problems that commonly occur in establishments on a day-to-day basis, derived from the support of a company with home delivery service in the state of Tlaxcala significant increase in customer complaints was detected, such as; they do not deliver as promised, slow service, poor attention from employees and even some complaints with food hygiene. The objective of the research is to analyze the perception and expectations of customers and identify the factors that impact the quality of the service received in Mexican food restaurants in the central area of the state of Tlaxcala, taking the Servqual model as a reference. The Servqual instrument adapted to 45 clients was applied to know their expectations and perceptions, the research was carried out in 3 Mexican food restaurants located in: Apizaco, Chiautempan and Tlaxcala Capital. The results showed that customers are not satisfied with the service they receive from restaurants because in the gap analysis all variables are negative, although the difference between expectations and perceptions is not so significant, so they generally agree. depending on the service received. The most critical variables or those with the greatest impact are responsiveness and empathy.

Keywords: Expectations, Perceptions, Quality analysis, Restaurant sector, Servqual model.
Submitted : December 31, 2021

Published : February 10, 2022

ISSN: $2507-1076$

DOI: $10.24018 /$ ejbmr.2022.7.1.1308

Sandra Karina Saldaña Conde *

Tecnológico Nacional de México,

(TecNM) / Instituto Tecnológico deApizaco (ITA), México.

(e-mail: m20371419@apizaco.tecnm.mx) Crisanto Tenopala Hernández

Tecnológico Nacional de México, (TecNM) / Instituto Tecnológico de Apizaco (ITA), México.

(e-mail: crisanto.th@apizaco.tecnm.mx) Elizabeth Montiel Huerta

Tecnológico Nacional de México, (TecNM) / Instituto Tecnológico de Apizaco (ITA), México.

(e-mail: elizabeth.mh@ apizaco.tecnm.mx) Gerardo Islas Téllez

Tecnológico Nacional de México, (TecNM) / Instituto Tecnológico de Apizaco (ITA), México

(e-mail: gerardo.it@apizaco.tecnm.mx) Alejandra Torres López

Tecnológico Nacional de México, (TecNM) / Instituto Tecnológico de Apizaco (ITA), México.

(e-mail: alejandra.tl@apizaco.tecnm.mx)

*Corresponding Author

\section{INTRODUCTION}

The quality of the service is the habit developed and practiced by an organization to interpret the needs and expectations of the clients and offer, consequently, an accessible, adequate, agile, flexible, appreciable, useful, timely, safe and reliable service, even under unforeseen situations or errors, in such a way that the client feels understood, cared for and cared for personally, with dedication and efficiency, and surprised with greater value than expected, consequently providing higher income and lower costs for the organization (Pizzo, 2013). As Edwards Deming (2013) said, "what is not measured cannot be improved". No company or organization can join in continuous improvement if it does not have a complete knowledge of its areas of opportunity. Mexican food is recognized throughout the world named by UNESCO in 2010 as a cultural heritage of humanity is a recognition and obligation of conservation and heritage that is undoubtedly part of a whole series of initiatives that must be launched now that the Mexican cuisine is in great demand throughout the country and with global recognition which must be preserved and maintained, so strategies are required to increase and / or improve the quality of services. On the other hand, the number of establishments that open each year exceeds the behavior of the demand for this type of services. Therefore, being a sector in constant growth and generating a significant economic spill in the country, always consider offering a quality service. If you want to improve the Mexican food restaurant industry, you have to start first by addressing all the problems that often occur in establishments on a daily basis. Really, know the level of satisfaction of the client for which it is proposed to use the SERVQUAL method. Tlaxcala's tourism sector is still below the state's potential. In 2006, temporary housing, food, and beverage preparation 
services, as well as recreational services accounted for $2.3 \%$ of the state's GDP. In 2015, these tourism-related services represented $1.10 \%$ of state GDP and registered an increase of $14 \%$ compared to the previous year, according to data from INEGI (2014). In 2020, restaurants have suffered very low sales, reporting a $50 \%$ drop due to the contingency situation that everyone is going through, sales have been below expectations and the restaurant industry is one of the most affected sectors according to Canirac (National Chamber of the Restaurant and Seasoned Food Industry). Given the situation, the customer every day becomes more demanding in terms of the quality of services, so that everyday complaints to establishments increase. In an interview with the call-center staff of the Food express mobile application (app dedicated to the delivery of food at home in the state of Tlaxcala) with a sample of 167 comments from the application, they mention that approximately 4 out of 10 customers per day are They complain of poor service in the restaurant related to: they do not comply with what was promised, they do not have the food established in their menu, outdated prices, food hygiene, they do not comply with the promised hours, among other aspects that generate dissatisfaction with the customer and comment that the complaints are in small restaurants, in some cases medium and mostly in the category of fast food, Mexican food, seafood and Japanese food located in the municipalities of Apizaco and Tlaxcala (Food Express, 2021). For this reason, this research proposes to analyze quality by mainly identifying the expectations and perceptions of customers in the restaurant sector of the state of Tlaxcala, which is one of the main sectors of Tourism in Mexico and thus obtain the level of customer satisfaction. In relation to the subject, a review of the literature was previously carried out where the researchers analyzed, for the most part, obtain negative results, that is, the clients are not satisfied with the service received. Due to the approach to the problem of this research, it is very important to carry it out to detect areas of opportunity in the restaurant sector of Tlaxcala. The researchers analyzed that focus on the restaurant industry only contemplate one company in the sector. It is also observed that in some cases, adaptations were made to the model, or another was used together and in the same way valuable information was obtained, which confirms that the combination of two epistemological axes is useful. Despite having mostly negative results, the authors refrain from proposing a model to improve quality and take advantage of the areas of opportunities detected, which are considered of utmost importance since they could add more value to entrepreneurs or businessmen and to the sector, for therefore general. The proposed research considers two important points that could add more depth of knowledge and they are: the study for a broader restaurant sector and a model of improvements for the sector.

\section{LITERATURE REVIEW}

\section{A. Quality}

It represents a process of continuous improvement, in which all areas of the company seek to satisfy the client's needs or anticipate them, actively participating in the development of products or in the provision of services (Álvarez, 2006).

\section{B. Service}

It is a means of delivering value to clients, facilitating the results that clients want to achieve without assuming specific costs or risks (Bon, 2008).

\section{Quality in the Service}

Hoffman and Baeston (2011) define service quality considering it as an attitude formed through the long-term general evaluation of a company's performance, since they see customer satisfaction as a specific measure of short-term operations of a company. The perception of quality is the level of service that the client qualifies subjectively close to his experience received from the service. The client perceives the services based on what is quality for him and to what extent he is satisfied. On the other hand, customer expectations are the level of service they expect to receive; Likewise, this level of expectations is different for each client (Sánchez \& Sanchez, 2016).

Finally, customer satisfaction is that in which their expectations are compared with their perceptions of the actual service contract (Hoffman and Bateson, 2011).

\section{Importance of Quality in Service}

The quality of customer service is one of the main points that must be met within each of the companies; Regardless of the size, structure, and nature of their operations, they must demonstrate the capacity they have to perform in this area, since being the first image that is given to clients helps to maintain their preference, and if it is altered it can become a threat. However, on many occasions it can be used by organizations incorrectly, affecting both their development and growth, therefore, mainly, the importance of said customer service must be defined, in order to properly structure the most optimal way to carry it out (Parra, 2013).

\section{E. Models to Measure Service Quality}

Quantifying the quality that the customer perceives of a service is not easy; It is necessary to use an instrument that supports organizations to understand the meaning of value for the client and diagnose if the activities carried out are aligned with the fulfillment of their needs. Faced with this need, various techniques and methodologies arise to measure customer satisfaction (Sánchez \& Sanchez, 2016).

Table I briefly describes the models that have been used to measure service quality within various organizations over the past 30 years.

\section{F. Target}

Analyze the perception and expectations of customers and identify the factors that impact on the quality of the service received, taking the servqual model as a reference and in this way propose a model to improve the quality of service in Mexican food restaurants in the center of the city town of the state of Tlaxcala. 
TABLE I: MODELS TO MEASURE QUALITY

\begin{tabular}{|c|c|c|c|c|}
\hline Year & Auhor & Model & Assessment & Dimensions \\
\hline 1984 & $\begin{array}{l}\text { Cristian } \\
\text { Grönroos }\end{array}$ & $\begin{array}{l}\text { Grönroos } \\
\text { service } \\
\text { quality } \\
\text { model }\end{array}$ & $\begin{array}{l}\text { Expectations } \\
\text { Perceptions }\end{array}$ & $\begin{array}{c}\text { Marketing } \\
\text { Prices } \\
\text { Previous experiences } \\
\text { Traditions } \\
\text { Ideologies } \\
\text { Mouth to mouth } \\
\text { Culture organizations } \\
\text { Philosophy } \\
\text { Tangible items }\end{array}$ \\
\hline 1988 & $\begin{array}{c}\text { Parasuraman, } \\
\text { Zeithaml and } \\
\text { Berry }\end{array}$ & Servqual & $\begin{array}{l}\text { Expectations } \\
\text { Perceptions }\end{array}$ & $\begin{array}{c}\text { Tangible items } \\
\text { Empathy } \\
\text { Reliability } \\
\text { Security } \\
\text { Answer's capacity } \\
\text { Tanoible items }\end{array}$ \\
\hline 1992 & $\begin{array}{c}\text { Cronin and } \\
\text { Taylor }\end{array}$ & Serpref & Percepctions & $\begin{array}{l}\text { Empathy } \\
\text { Reliability } \\
\text { Security } \\
\text { Answer's capacity }\end{array}$ \\
\hline 1994 & $\begin{array}{l}\text { Rust \& } \\
\text { Oliver }\end{array}$ & $\begin{array}{c}3 \\
\text { component } \\
\text { model }\end{array}$ & $\begin{array}{l}\text { Expectations } \\
\text { Perceptions }\end{array}$ & $\begin{array}{c}\text { Cultural Organizations } \\
\text { Philosophy } \\
\text { Tangible elements } \\
\text { Empathy } \\
\text { Reliability } \\
\text { Security } \\
\text { Answer's capacity } \\
\text { Characteristics } \\
\text { Objectives }\end{array}$ \\
\hline
\end{tabular}

\section{METHODOLOGY}

The data collection for the research is through a questionnaire based on the Servqual model proposed and designed by Zeithaml, Parasuraman and Berry (1988) whose purpose is to improve the quality of the service offered by an organization. Servqual consists of 5 dimensions and a total of 22 elements. However, an adaptation was made to the model and the instrument to be applied was added two extra variables that are Hygiene and Advertising, in addition to adding items in the variable safety related to the hygiene measures that the restaurant has regarding Covid 19 this due the change that has taken place today in the face of the pandemic that is being experienced around the world and that have been important factors that the client considers to go out to eat at restaurants in addition to the advertising variable is also considered by the technological changes that are They have increased in recent years, especially the change in digital marketing and that also represent a great importance for the client when it comes to acquiring a service and of course being evaluated. The model used is shown in Table II.

The servqual model is chosen because, according to Vera \& Trujillo (2017), it is one of the most widely used and reliable instruments to measure service quality. Furthermore, compared to other models such as SERVFREP, the Grönroos service quality model or the three-component model, Servqual is one of the main sources of information as it detects quality dimensions in a timely manner, which is why servqual is a one of the most accurate. Models for service companies to know the level of customer satisfaction, locate areas of opportunity and propose and/or implement improvements to have satisfied customers ((Monrroy \& Urcádiz , 2018)). The instrument was adapted to the research needs and some changes were also considered due to the current need in the sector.
TABLE II: ADAPTED SERVQUAL MODEL

\begin{tabular}{|c|c|}
\hline Variable & Item \\
\hline $\begin{array}{l}\text { Answer's } \\
\text { capacity }\end{array}$ & $\begin{array}{l}\text { 1. Employees offer fast service } \\
\text { 2. Consider that employees are willing to help } \\
\text { 3. Employees are available to correctly answer any } \\
\text { questions you may have. } \\
\text { 4. How do you consider the restaurant's home } \\
\text { delivery service? } \\
\text { 5. How do you consider the reservation service of this } \\
\text { restaurant? }\end{array}$ \\
\hline Security & $\begin{array}{l}\text { 6. Employees have trustworthy behavior } \\
\text { 7. You feel confident with the service the restaurant } \\
\text { offers. } \\
\text { 8. Employees have a friendly demeanor } \\
\text { 9. Employees have sufficient knowledge in service. } \\
\text { 10. The facilities are with adequate distribution of } \\
\text { spaces. } \\
\text { 11. They take your temperature when entering the } \\
\text { restaurant } \\
\text { 12. The restaurant has sanitizing gel } \\
\text { 13. The restaurant has soap in the bathrooms. } \\
\text { 14. Employees use mouth guard correctly }\end{array}$ \\
\hline $\begin{array}{l}\text { Tangible } \\
\text { items }\end{array}$ & $\begin{array}{l}\text { 15. The restaurant has modern-looking equipment } \\
\text { 16. The restaurant has visibly attractive facilities } \\
\text { 17. General restaurant facilities are clean } \\
\text { 18. The restaurant's work materials are attractive } \\
\text { (menu, advertising, social networks, etc.) }\end{array}$ \\
\hline Empathy & $\begin{array}{l}\text { 19. You receive individualized attention } \\
\text { 20. You are satisfied with the restaurant's service } \\
\text { hours } \\
\text { 21. Employees offer you personalized attention } \\
\text { 22. Employee care about meeting your needs } \\
\text { 23. The restaurant service cares about your interests } \\
\text { and / or wishes }\end{array}$ \\
\hline Reliability & $\begin{array}{l}\text { 24. The restaurant fulfills the promised service } \\
\text { 25. If you have a problem related to the restaurant } \\
\text { service, show interest in helping to solve it } \\
\text { 26. Restaurant service is done right from the first } \\
\text { time } \\
27 \text {. The restaurant concludes its service in the } \\
\text { promised time } \\
\text { 28. The restaurant does not make mistakes in terms } \\
\text { of service (taking orders, collecting tickets) } \\
\text { 29. The restaurant has all the foods described in its } \\
\text { menu } \\
\text { 30. The restaurant offers a wide variety of dishes on } \\
\text { its menu } \\
31 \text {. In general terms, how do you consider the quality } \\
\text { of the restaurant? }\end{array}$ \\
\hline Hygiene & $\begin{array}{l}\text { 32. The restaurant manages adequate hygiene in its } \\
\text { food } \\
\text { 33. The restaurant offers fresh food }\end{array}$ \\
\hline Publicity & $\begin{array}{l}\text { 34. It is important for the restaurant to advertise its } \\
\text { social networking services } \\
\text { 35. It is important that the restaurant has home } \\
\text { delivery service through the new mobile applications } \\
\text { 36. It is important that the restaurant is advertised } \\
\text { through printed advertising (banners, brochures, etc.) }\end{array}$ \\
\hline
\end{tabular}

\section{A. Instrument Validation}

The data collection instrument was validated using the Cron Bach alpha method by applying 35 test surveys in three restaurants in the municipalities; Apizaco, Tlaxcala and Chiuatempan, the results were as follows:

Cron Bach's Alpha: The reliability analysis was performed with SPSS version 21 software and the results are shown in Table III.

TABLE III: RELIABILITY STATISTICS

\begin{tabular}{cc}
\hline \hline Cronbach's alpha & No. of elements \\
\hline 0.917 & 36 \\
\hline \hline
\end{tabular}


The reliability result of Cronbach's alpha corresponds to 0.917 , which according to Table IV can be interpreted with excellent reliability.

TABLE IV: ASSESSMENT OF ITEM RELIABILITY ACCORDING TO CRONBACH'S ALPHA COEFFICIENT

\begin{tabular}{cc}
\hline $\begin{array}{c}\text { Interval to which the Cron Bach } \\
\text { alpha coefficient belongs }\end{array}$ & $\begin{array}{c}\text { Evaluation of the reliability of the } \\
\text { items analyzed }\end{array}$ \\
\hline $0 ; 0,5]$ & Unacceptable \\
{$[0,5 ; 0,6]$} & Poor \\
{$[0,6 ; 0,7]$} & Weak \\
{$[0,7 ; 0,8]$} & Acceptable \\
{$[0,8 ; 0,9]$} & Okay \\
{$[0,9 ; 1]$} & Excellent \\
\hline \hline
\end{tabular}

\section{RESULTS}

The data collection instrument was used in 45 people, the same instrument was applied to each one twice, once before entering the restaurant (expectation) and once after receiving the service (perception) with a total of 90 surveys in 3 different Mexican food restaurants in the state of Tlaxcala. Of which $36.5 \%$ of the respondents were men while $64.4 \%$ were women, aged between 14 and 54 years from the municipality of Tlaxcala. The Mexican food restaurants under study are shown in Table V.

The data matrix was made for each item. Subsequently, the items were grouped for each variable to be measured. Once the grouping of items by variables has been obtained, the sequence of data exploration as well as expectations and perceptions is carried out through the calculation of averages according to (Hernandez, Fernandez, \& Baptista, 2006).

Subsequently, the mode and the range of expectations and perceptions are obtained in Tables VI and VII.
TABLE V: RESTAURANTS UNDER STUDY

\begin{tabular}{|c|c|c|c|c|}
\hline $\begin{array}{l}\text { Name of } \\
\text { the } \\
\text { restaurant }\end{array}$ & Address & Size & $\begin{array}{c}\text { No. of } \\
\text { expectations } \\
\text { surveys }\end{array}$ & $\begin{array}{c}\text { No. of } \\
\text { surveys } \\
\text { perceptions }\end{array}$ \\
\hline $\begin{array}{c}\text { Restaurante } \\
\text { Mandinga }\end{array}$ & $\begin{array}{c}\text { Porfirio Díaz 10- } \\
\text { Planta Alta, Centro, } \\
90000 \text { Tlaxcala de } \\
\text { Xicohténcatl, Tlax }\end{array}$ & Pequeño & 15 & 15 \\
\hline $\begin{array}{l}\text { Honorina el } \\
\text { gran sabor } \\
\text { de Tlaxcala }\end{array}$ & $\begin{array}{l}\text { Blvd. Mariano } \\
\text { Sánchez 57, Centro, } \\
90000 \text { Tlaxcala de } \\
\text { Xicohténcatl, Tlax. }\end{array}$ & Pequeño & 15 & 15 \\
\hline $\begin{array}{l}\text { Taquería } \\
\text { "La gran } \\
\text { avenida" }\end{array}$ & $\begin{array}{l}\text { Gabino A. Palma } \\
\text { 103, Ocotlán, } 90030 \\
\text { Tlaxcala de } \\
\text { Xicohténcatl, Tlax. }\end{array}$ & Pequeño & 15 & 15 \\
\hline
\end{tabular}

\section{A. GAP Analysis}

Once the information of each of the variables of the surveys carried out by 45 clients in 3 Mexican food restaurants in the state of Tlaxcala has been analyzed and interpreted, considering home delivery and reservations, the following results are obtained, showing the global averages by variable, and are observed in Fig. 1 and Table VIII.

TABLE VIII: GAP ANALYSIS

\begin{tabular}{cccc}
\multicolumn{4}{c}{ TABLE VIII: GAP ANALYSIS } \\
\cline { 2 - 4 } Variable & \multicolumn{3}{c}{ Averages } \\
\cline { 2 - 4 } & Expectations & Perception & GAP (P-E) \\
\hline Answer's capacity & 4.99111111 & 3.85333333 & -1.13777778 \\
Security & 5 & 4.54377778 & -0.45622222 \\
Tangible items & 5 & 4.43333333 & -0.56666667 \\
Empathy & 5 & 4.31111111 & -0.68888889 \\
Reliability & 5 & 4.40155556 & -0.59844444 \\
Hygiene & 5 & 4.62222222 & -0.37777778 \\
Publicity & 5 & 4.59244444 & -0.40755556 \\
\hline \hline
\end{tabular}

\begin{tabular}{|c|c|c|c|c|c|c|c|c|}
\hline & & $\begin{array}{l}\text { Anwser } \\
\text { Capacity }\end{array}$ & Segurity & $\begin{array}{l}\text { Tangible } \\
\text { Items }\end{array}$ & Empathy & Reliability & Hygiene & Publicity \\
\hline \multirow{2}{*}{$\mathrm{N}$} & Valid & 45 & 45 & 45 & 45 & 45 & 45 & 45 \\
\hline & Lost & 0 & 0 & 0 & 0 & 0 & 0 & 0 \\
\hline \multirow{2}{*}{\multicolumn{2}{|c|}{$\begin{array}{l}\text { Median } \\
\text { Rank }\end{array}$}} & 5.0000 & 5.0000 & 5.0000 & 5.0000 & 5.0000 & 5.0000 & 5.0000 \\
\hline & & 0.40 & 0.00 & 0.00 & 0.00 & 0.00 & 0.00 & 0.00 \\
\hline \multicolumn{9}{|c|}{ TABLE VII: STATISTICAL PERCEPTIONS } \\
\hline & & $\begin{array}{c}\text { Answer } \\
\text { Capacity }\end{array}$ & Segurity & $\begin{array}{c}\text { Tangible } \\
\text { Items }\end{array}$ & Empathy & Reliability & Hygiene & Publicity \\
\hline & Valid & 45 & 45 & 45 & 45 & 45 & 45 & 45 \\
\hline & Lost & 0 & 0 & 0 & 0 & 0 & 0 & 0 \\
\hline \multicolumn{2}{|c|}{ Median } & 4.7778 & 4.5000 & 4.4000 & 4.3750 & 5.0000 & 5.0000 & 4.7778 \\
\hline \multicolumn{2}{|c|}{ Rank } & 2.00 & 2.75 & 2.80 & 2.75 & 2.00 & 2.00 & 2.00 \\
\hline
\end{tabular}

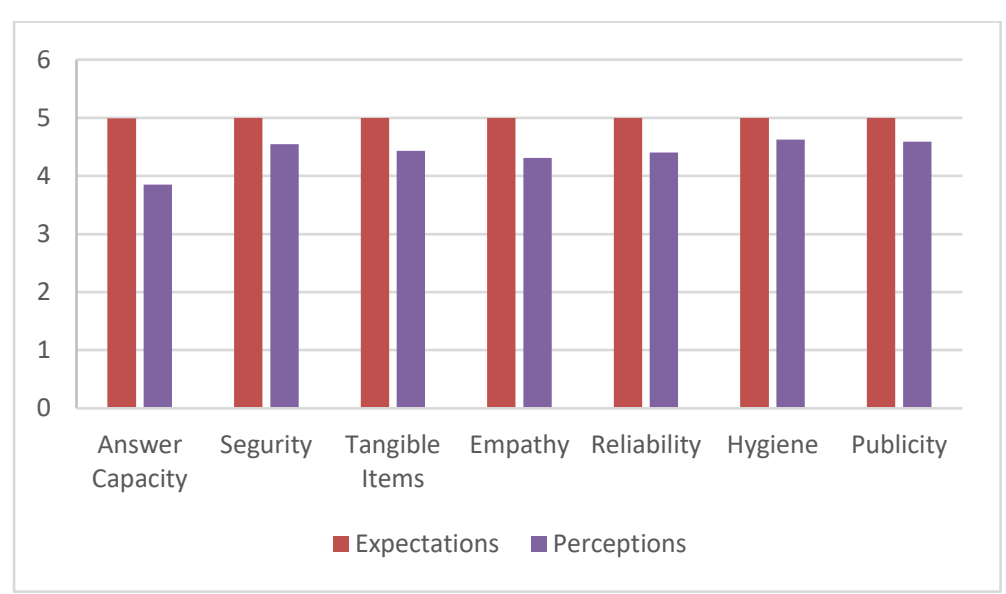

Fig. 1. GAP Analysis. 


\section{CONCLUSION}

Finally, it can be concluded that according to the data analyzed, in general customers agree with the service offered by Mexican food restaurants in the state of Tlaxcala, however there are gaps with negative global averages that, although they are not so significant, it is important to attend. The hygiene and publicity variables are the least critical, the gap is not very significant. The most critical variables are responsiveness and empathy with a difference of -1.1377 and -0.6888 , respectively. The improvement model must include strategies specifically to consider the inclusion of catering in new technologies such as home service applications and social networks, since the instrument indicates that customers consider it of utmost importance. We must pay attention and improve the security, responsiveness, and empathy variables since, derived from the GAP gap analysis, they are the most critical with a slightly more significant difference, so that customers are still not completely satisfied with the service they receive. The level of satisfaction perceived by customers in Mexican food restaurants in the central area of the state of Tlaxcala is unsatisfied, since according to the analysis of the gaps, the customer does not receive the service they expect. It is considered that the quality level of the restaurants is also a bit low due to the fact that the restaurant does not adequately meet the customer's expectations, however the differences and gaps are not very significant so the quality cannot be considered $100 \%$ bad but if it is an opportunity to improve areas of opportunity that were found in the research.

\section{REFERENCES}

Berenice. (25 de junio de 2018). Superprof. Obtenido de https://www.superprof.mx/blog/cocina-mexicana-en-el-extranjero/.

Charris, A., Guerrero, E., \& Rodriguez, E. (2019). Mejora Continua del Servicio al Cliente Mediante ServQual y Red de Petri en un Restaurante de Santa Marta, Colombi. Revista Información Tecnologica, 12.

Chavez, E., \& Rodriguez, L. (2019). Análisis de confiabilidad y validez de un cuestionario sobre entornos personales de aprendizaje (PLE). Ensayos Pedagógicos, 2-3.

Espinoza, L., Ulibarri, H., \& Pereyra, A. (2016). Expectativas y percepciones de los clientes de un restaurante en la ciudad de Mérida,Yucatán. Reaxion Ciencia y Tecnologia Universitaria, 7.

Ganga, F., Halarcon, N., \& Pedraja, L. (2019). Medición de calidad de servicio mediante el modelo SERVQUAL: el caso del Juzgado de Garantía de la ciudad de Puerto Montt - Chile. Revista Chilena de Ingeniería, 14

Hernandez, R., Fernandez, C., \& Baptista, P. (2006). Metodología de la investigación. México: McGraw-Hill.

Lara, E., \& Pereyra, A. (2017). Expectativas y percepciones de los clientes de las microempresas en Dzityá. Ecorfan, 18-25.

Martínez, R., Tuya, L., Peréz, A., \& Cánovas, A. (2009). EL Coeficiente de Correlación de los Rangos de Spearman. Instituto Superior de Ciencias Médicas de La Habana (ISCM-H), 4-10.

Monrroy, A., \& Urcádiz, F. (2018). Calidad en el servicio y su incidencia en la satisfacción del comensal en restaurantes. Redalyc, 21.

Núñez, L., \& Júarez, J. (2018). Análisis comparativo de modelos de evaluación de calidad en el servicio a partir de sus dimenciones y su relación con la satosfacción del cliente. 3 ciencias, 9 .

Parra, M. (2013). Importancia de la calidad del servicio del cliente. El buzón de pacioli, 7-15.

Restaurante Porfirios. (25 de febrero de 2020). Porfirios Restaurante. Obtenido de https://porfirios.com.mx/blog/restaurante-de-comidamexicana/.

Rodriguez, M. (2017). Plan Estatal de Desarrollo. Tlaxcala: Gobierno del Estado de Tlaxcala.

Sánchez, J. (16 de febrero de 2016). Economipedia. Obtenido de https://economipedia.com/definiciones/servicio.html.

Sánchez, M., \& Sanchez, M. (2016). Medición de la calidad en el servicio, como estrategia para la competitividad. 2-4.
SN Digital, T. (26 de Febrero de 2021). SN Digital Tlaxcala. Obtenido de http://www.sndigital.mx/78304-incluyen-a-restaurantes-evoka-casabernabe-y-mexko-en-la-guia-mexico-gastronomico-2021.html.

Trejo, S. (22 de Junio de 2021). Msn Estilo de Vida. Obtenido de https://www.msn.com/es-mx/recetas/noticias/ganan-cocineras-detlaxcala-e-hidalgo-concurso-a-qu\%C3\%A9-sabe-la-patria-2021/arAALksU4?li=AAggxAT.

Deming, W. E. (1989). Calidad, productividad y competitividad: La salida de la crisis. Madrid España: Ediciones Díaz Santos.

Express, F. (05 de enero de 2021). Base de datos Food Express. Obtenido de www.foodexpress.com.mx

Hoffman, K. D., \& Bateson, J. E. (1997). Essentials of services marketing. Fort Worth, Dryden Press.

Pizzo, M. (10 de Julio de 2013). Calidad en el servicio. Un plan de mejora simple, inmediato y con impacto en el cliente. Obtenido de De gerente.com: https://degerencia.com/articulo/calidad-en-el-servicioun-plan-de-mejora-simple-inmediato-y-con-impacto-en-el-cliente/.

Parasuraman, A., Zeithaml, V. A., \& Berry, L. L. (1988). SERVQUAL - A multiple item scale for measuring consumer perceptions of service quality. Journal of Retailing. 12-40.

Vera, J., \& Trujillo, A. (2017). Escala mexicana de calidad en el servicio en restaurants (EMCASER). Innovar, Revista de Ciencias Administrativas y Sociales. 43-59. 